\title{
WOKÓŁ SOBORU NICEJSKIEGO (325): NA KANWIE MONOGRAFII AUTORSTWA HENRYKA PIETRASA SJ
}

Sobór zwołany przez cesarza Konstantyna Wielkiego do Nicei w roku 325 od wielu lat wciąż budzi żywe zainteresowanie badaczy na całym świecie ${ }^{1}$. $\mathrm{Na}$ tym tle dorobek polskiej nauki wygląda dość skromnie ${ }^{2}$. Z tym większym uznaniem trzeba odnotować pojawienie się w języku polskim publikacji na temat soboru w Nicei, której autorem jest Henryk Pietras ${ }^{3}$, uznany patrolog,

* Dr hab. Sławomir Bralewski, prof. UŁ - profesor nadzwyczajny w Katedrze Historii Bizancjum w Instytucie Historii na Wydziale Filozoficzno-Historycznym Uniwersytetu Lódzkiego; e-mail: sbralewski@o2.pl.

1 Por. m.in. C.J. Hefele, Histoire des conciles d'après les documents originaux, trad. H. Leclerq, t. 1, Paris 1907, 335-632; A. d'Alès, Le dogme de Nicée, Paris 1926; I. Ortiz de Urbina, Nicée et Constantinople, Paris 1963; M. Simonetti, La crisi ariana nel IV secolo, Roma 1975; G.C. Stead, Divine Substance, Oxford 1977; T.D. Barnes, Constantine and Eusebius, London 1981; C. Luibhéid, The Council of Nicea, Galway 1982; R. Williams, Arius: Heresy and Tradition, London 1987; R.P.C. Hanson, The Search for the Christian Doctrine of God. The Arian Controversy 318381, Edinburgh 1988; L. Ayres, Nicaea and its Legacy. An Approach to Fourth-Century Trinitarian Theology, Oxford 2004, 11-104, gdzie auor zebrał bogatą literaturę na s. 436-464; J. Behr, The Nicene Faith, Crestwood - New York 2004; T.C. Ferguson, The Past is Prologue. The Revolution of Nicene Historiography, Leiden - Boston 2005, 1-170 (bibliografia: s. 171-177); K. Anatolios, Retrieving Nicaea.The Development and Meaning of Trinitarian Doctrine, Michigan 2011.

${ }^{2}$ Por. J. Woliński, Sobór Nicejski zwrotnym punktem w nauczaniu patrystyki, VoxP 9 (1989) t. 16, 191-211; J. Gliściński, Wspótistotny Ojcu, Łódź 1992; J. Słomka, Z historii interpretacji nicejskiego wyznania wiary, „Łódzkie Studia Teologiczne” 3 (1994) 323-338; M. Starowieyski, Sobory Kościoła niepodzielonego, Tarnów 1994, 17-33; J. Słomka, Symbol Nicejski, w: Wolność w prawdzie. Księga Jubileuszowa Instytutu Teologicznego w Łodzi, red. S. Skobel, Łódź 1997, 125-140; S. Bralewski, Polityka Konstantyna Wielkiego wobec Arian po soborze w Nicei: nagły zwrot czy kontynuacja?, VoxP 18 (1998) t. 34-35, 335-355; H. Pietras, Le ragioni della convocazione del Concilio Niceo da parte di Constantino il Grande. Un'investigazione storico-teologica, „Gregorianum” 82/1 (2001) 5-35; S. Longosz, Liczba uczestników I Soboru Nicejskiego (325) w relacji Ojców Kościoła IV w., w: Ku prawdzie w miłości. Księga Pamiatkowa ks. bpa J. Śrutwy, red. S. Koczwara, Lublin 2002, 71-86; H. Pietras, List Konstantyna do Aleksandra i Ariusza a zwołanie soboru Nicejskiego, VoxP 26 (2006) t. 64, 531-547; D. Spychała, Cesarze rzymscy a arianizm od Konstantyna Wielkiego do Teodozjusza Wielkiego (312-395), Poznań 2007, 141-158; J. Grzywaczewski, Okoliczności zwołania Soboru Nicejskiego, VoxP 34 (2014) t. 62, 139-168.

${ }^{3}$ Por. H. Pietras, Sobór Nicejski (325). Kontekst religijny i polityczny, dokumenty, komentarze, Kraków 2013. 
o poważnym dorobku naukowym, autor licznych publikacji, także o zasięgu międzynarodowym, współautor serii wydawniczych poświęconych soborom ${ }^{4}$ i synodom ${ }^{5}$. Wspomniana monografia jest unikatowym na gruncie polskim dziełem w całości poświęconym pierwszemu soborowi. Książka została oparta na artykułach wcześniej już publikowanych ${ }^{6}$, ale - jak sam Autor informuje we wstępie - szereg kwestii przemyślał na nowo. H. Pietras zestawił w niej teksty dotyczące początków kontrowersji ariańskiej, a także dokumenty związane z samym soborem, na które składają się ułożone tam credo czy kanony oraz dokumenty posoborowe czyli publikowane po zakończeniu obrad listy. Z wyjątkiem kanonów wszystkie zacytowane teksty zostały zaprezentowane w oryginale i thumaczeniu polskim. Autor nie zadowolił się samym ich zestawieniem, ale dokonał ich gruntownej, solidnej analizy, dociekając przy tym przyczyn zwołania soboru i wskazując na jego dokonania.

H. Pietras, badając źródła dotyczące kontrowersji ariańskiej, postawił wiele tez, których prawdziwości starał się dowieść. Przeprowadził ciekawą analizę teologiczną poglądów Ariusza, opierając się nie tylko na jego spuściźnie, ale też wykorzystując teksty Tertuliana, Orygenesa, Justyna czy Dionizego Aleksandryjskiego. Badacz zwrócił uwagę, że przyjęło się nazywać kontrowersję ariańską sporem trynitarnym, w odróżnieniu od późniejszych kontrowersji chrystologicznych. W jego przekonaniu taki obraz narzucił prawdopodobnie Atanazy, który mówił przede wszystkim o relacji Ojca do Syna, i który był odpowiedzialny za ukształtowanie wyobrażeń o arianizmie. Uczestnicy synodu w Antiochii (324/325) wskazywali na dyskusję dotyczącą samego Zbawiciela, „a nie Jego relacji pochodzenia od Ojca”, tak więc spór, zdaniem Pietrasa, miał bardziej charakter chrystologiczny niż trynitarny?

Autor dowodził też, że fragment Księgi Przysłów (8, 22-25), uważany powszechnie przez badaczy za kluczowy dla toczonej wówczas dysputy teologicznej, nie miał tak zasadniczego znaczenia, jak mu się przypisuje. Pojawia się bowiem w niej rzadko. Badacz doszukał się jedynie jego dwukrotnego użycia: raz w Liście Euzebiusza z Nikomedii do Paulina z Tyru oraz drugi raz w Liście Ariusza do Euzebiusza z Nikomedii ${ }^{9}$. Na podstawie ustępu Listu Aleksandra

${ }^{4}$ Por. Dokumenty Soborów Powszechnych, t. 1-4, Kraków 2001-2004.

${ }^{5}$ Por. Synody i Kolekcje Praw, Kraków 2006-.

${ }^{6}$ Por. Pietras, Le ragioni della convocazione del Concilio Niceo, s. 5-35; tenże, Poczatek ,kontrowersji ariańskiej”, Zeszyty Naukowe UJ, Studia Religiologica 39, Kraków 2006, 57-79; tenże, List Konstantyna do Aleksandra i Ariusza a zwołanie soboru Nicejskiego, s. 531-547; tenże, List Konstantyna do Kościoła Aleksandrii oraz list soborowy do Egipcjan (325) - falsyfikaty nieznane Atanazemu?, VoxP 28 (2008) t. 52/2, 855-869.

${ }^{7}$ Por. tenże, Sobór Nicejski, s. 132.

${ }^{8}$ Por. Epistula Eusebii Nicomediensis ad Paulinum Tyronensis, ed. L. Parmentier- G.C. Hansen, w: Theodoretus Cyrensis, HE I 6, 1-8, GCS NF 5, Berlin - New York 2009, 27-29. Zob. Pietras, Sobór Nicejski, s. 63.

${ }^{9}$ Por. Epistula Arii presbiteri ad Eusebium Nicomediensis, ed. L. Parmentier - G.C. Hansen, w: Theodoretus Cyrensis, HE I 5, 1-4, GCS NF 5, 26-27. Zob. też Pietras, Sobór Nicejski, s. 74. 
z Aleksandrii do Aleksandra z Konstantynopola ${ }^{10}$, gdzie mowa jest o tym, że Ariusz i jego zwolennicy zestawili ze sobą cytaty z Pisma Świętego, mówiące o uniżeniu Zbawiciela (np. Flp 2, 6-10), co posłużyło im do negowania Jego bóstwa, H. Pietras doszedł do wniosku, że to te teksty biblijne były zasadnicze dla nauczania Ariusza ${ }^{11}$. Analizując źródła dotyczące początków kontrowersji ariańskiej, Badacz zwrócił uwagę, że Ariusz kładł nacisk na zmienność z natury Syna, który z własnej woli pozostawał niezmiennie dobrym. Właściwa Mu była bowiem możliwość wyboru dobra i zła. Zmienność Logosu wynikała z konsekwencji Jego zrodzenia, typowej dla wszystkich bytów zrodzonych ${ }^{12}$.

Zdaniem Autora nie ma dowodów na to, wbrew powszechnemu przekonaniu, że Ariusz był uczniem Lucjana z Antiochii. Nazwanie przezeń Euzebiusza z Nikomedii ,prawdziwym kollucjanistą ( $\sigma 0 \lambda \lambda \sigma v \kappa \imath \alpha v \imath \sigma \tau \grave{\alpha} \alpha \dot{\alpha} \lambda \eta \theta \hat{\omega} \varsigma$

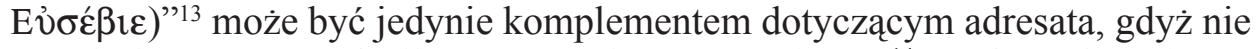
mówi nic na temat relacji samego Ariusza z Lucjanem ${ }^{14}$. Badacz słusznie też konstatuje, że list Ariusza do Aleksandra poprzedzał chronologicznie potępienie herezjarchy i podpisanych pod listem sygnatariuszy, bowiem jako potępieni zostali oni wymienieni w liście Aleksandra do wszystkich biskupów niemal w tej samej kolejności, w jakiej podpisali się pod listem Ariusza ${ }^{15}$.

Najważniejsze tezy postawione przez Autora dotyczą samego soboru w Nicei. Według niego sobór nie został zwołany przez cesarza Konstantyna z powodu arianizmu, lecz z racji jubileuszu dwudziestolecia jego rządów. Jak ujął to Autor:

„[władca] przy tej podniosłej okazji zamierzał ogłosić uroczyście pojednanie wszystkich zwaśnionych stron, kalendarz paschalny oraz podstawową formułę wiary chrześcijańskiej”"16.

W przekonaniu H. Pietrasa kontrowersja ariańska rozpoczęła się w stosunkowo krótkim okresie przed zwycięstwem Konstantyna nad Licyniuszem, najprawdopodobniej ok. roku 323, a nie w 318 czy 320, ,jak chcą zwolennicy twierdzenia, że przed rokiem 325 arianizm urósł do rangi najważniejszego problemu w Kościele"17. Kontrowersja nie zdążyła zatem rozprzestrzenić się na tyle, by stać się konfliktem ogólnokościelnym. Tak więc, kiedy zainteresował się nią cesarz, miała charakter lokalny. Sam władca uważał ją za pozbawioną większego znaczenia błahostkę. Badacz przypuszcza, że Konstantyn musiał znać sprawę z drugiej ręki i wskazuje na Euzebiusza z Nikomedii jako

\footnotetext{
${ }^{10}$ Por. Epistula Alexandri Alexandrini ad Alexandrum Constantinopolitanum, ed. L. Parmentier - G.C. Hansen, w: Theodoretus Cyrensis, HE I 4, 1-61, GCS NF 5, 8-25.

${ }^{11}$ Por. Pietras, Sobór Nicejski, s. 69 i 107.

${ }^{12}$ Por. tamże, s. 24, 44-45 i 73-74.

${ }^{13}$ Por. Epistula Arii presbiteri ad Eusebium Nicomediensis, GCS NF 5, 27.

${ }^{14}$ Por. Pietras, Sobór Nicejski, s. 60 i 107.

${ }^{15}$ Por. tamże, s. 33.

16 Tamże, s. 137.

${ }^{17}$ Tamże, s. 68.
} 
biskupa siedziby cesarskiej, w której władca przebywał, i Hozjusza z Kordoby, zaufanego doradcę w kwestiach kościelnych, jako na tych duchownych, którzy prawdopodobnie mieli w zasadniczy sposób wpływać na opinię władcy ${ }^{18}$.

H. Pietras neguje ${ }^{19}$ informacje podane przez Epifaniusza z Salaminy ${ }^{20}$ i Filostorgiusza ${ }^{21}$ na temat podróży przedsięwziętych przez Ariusza do Palestyny i Bitynii, zanim jeszcze Konstantyn wysłał List do Aleksandra z Aleksandrii $i$ Ariusza. Patrolog zastanawia się, czy gdyby wcześniej odbył się synod w Nikomedii w sprawie Ariusza albo Aleksander zdążył wysłać listy w sprawie herezjarchy, to czy cesarz mógłby o tym nie wiedzieć? Zdaniem Badacza, gdyby było inaczej, wtedy problem stałby się ogólnokościelny, a cesarski list winien być skierowany wówczas do Aleksandra, biskupa Aleksandrii i Euzebiusza, biskupa Nikomedii. H. Pietras nie bierze jednak pod uwagę, że Konstantyn miał za sobą nieudane doświadczenie zażegnania schizmy donacjańskiej, kiedy to władca od początku swego zaangażowania stanął po stronie przeciwników donatystów, co jednak nie przyniosło oczekiwanego przez niego rezultatu i nie doprowadziło do przywrócenia pokoju w Kościele afrykańskim ${ }^{22}$. Tym razem więc cesarz podjął próbę wygaszenia rozprzestrzeniającego się konfliktu u jego źródła, nie rozumiejąc jego istoty, ale mając nadzieję, że autorytet monarszy weźmie górę nad ambicjami duchownych. Tym bardziej że, jak wskazuje sam Autor i niewątpliwie ma rację, cesarski list był tylko formalnie adresowany do Aleksandra i Ariusza ${ }^{23}$, a w rzeczywistości miał charakter listu okólnego, skierowanego do większej ilości adresatów ${ }^{24}$. Z treści listu wynika, że byli nimi biskupi Wschodu, do których władca także apelował o zaniechanie sporów ${ }^{25}$. Jeśli więc cesarz nadał wspomnianemu pismu charakter okólny, to spór w jego przekonaniu nie był lokalny. H. Pietras żywi też wątpliwości co do dużej liczby listów słanych przez skłócone strony, w tym przez Euzebiusza z Nikomedii ${ }^{26}$, konstatując, że zachował się tylko jeden z nich, wysłany do Paulina z Tyru, a zamieszczony przez Teodoreta z Cyru w jego Historii kościelnej27.

Datując początki kontrowersji ariańskiej na rok 323, Badacz przygotowywał jedną z zasadniczych tez zaprezentowanych we wspomnianej książce - nie tylko o lokalnym charakterze, lecz także o niewielkim znaczeniu sporu

${ }^{18}$ Por. tamże, s. 110.

${ }^{19}$ Por. tamże, s. 61.

${ }^{20}$ Por. Epiphanius, Panarion 69, 4, ed. K. Hall - J. Dummer, GCS 37, Berlin - New York 2009, 109.

${ }^{21}$ Por. Philostorgius, HE I 7a, ed. J. Bidez - F. Winkelmann, GCS 21, Berlin $1981^{3}, 8$.

${ }^{22}$ Por. S. Bralewski, Czy cesarz Konstantyn Wielki zabiegat o kompromis z donatystami?, VoxP 20 (2000) t. 38-39, 427-448.

${ }^{23}$ Por. Epistula Constantini imperatoris ad Alexandrum Alexandrinum et Arium, ed. F. Winkelmann, w: Eusebius, Vita Constantini II 64-72, GCS 7, Berlin - New York 2008, 74-79.

${ }^{24}$ Por. Pietras, Sobór Nicejski, s. 99 i 104.

${ }^{25}$ Por. Epistula Constantini imperatoris ad Alexandrum Alexandrinum et Arium, w: Eusebius, Vita Constantini II 67, GCS 7, 74.

${ }^{26}$ Por. Pietras, Sobór Nicejski, s. 61-62.

${ }^{27}$ Por. Epistula Eusebii Nicomediensis ad Paulinum Tyronensis, GCS NF 5, 27-29. 
pomiędzy Aleksandrem i Ariuszem. Zajmując się nim H. Pietras wymiennie używa pojęcia: kontrowersja ariańska, spór i arianizm. Wydaje się to nieuzasadnione. Trudno mówić o arianizmie w tym czasie ${ }^{28}$. Niewątpliwie bardzo poważnym problemem był natomiast spór, który rozpętał się wokół nauczania Ariusza. O jego brzemiennych skutkach wspominał sam Euzebiusz, a także cesarz Konstantyn, uważając jego konsekwencje za bardziej dotkliwe dla Kościoła i pomyślności swego panowania niż schizma donacjańska, co władca wyraził dobitnie w Liście do Aleksandra i Ariusza ${ }^{29}$, a na co zwrócił uwage także krakowski Patrolog 30 .

Przede wszystkim wydaje się, że Euzebiusz przywiązywał dużo większą wagę do kontrowersji ariańskiej niż sugeruje to H. Pietras. Biskup Cezarei pisał bowiem w Vita Constantini o „poważnym zamieszaniu, które zagroziło poko-

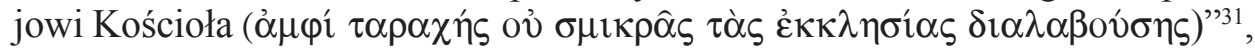
$\mathrm{o}$,klęsce czy nieszcześciu ( $\pi \lambda \eta \gamma \eta \eta^{\prime}{ }^{\prime 32}$, jakim dla cesarza był wspomniany konflikt, wzniecony przez ducha zawiści, który wywołał wśród biskupów „niezgodę i kłótnie o Boskie dogmaty"33. W końcu jednak konstatuje:

„Wskutek tego, jakby od małej iskierki, wybuchł ogromny pożar. Rozpoczął się w Kościele aleksandryjskim jak od czubka głowy, po czym ogarnął cały Egipt i Libię, docierając aż do Tebaidy. Ostatecznie spustoszył także pozostałe prowincje i miasta Cesarstwa tak, że nie tylko przełożeni Kościołów walczyli z sobą w wojnie na słowa, lecz także cały lud zupełnie się podzielił, jedni przystępując do tej frakcji, a drudzy do tamtej. W teatrze tych wydarzeń rzeczy doszły do takiego stopnia zepsucia i skandalu, że wśród niewierzących czcigodne doktryny natchnionej nauki były wyszydzane, przytaczane jak najbardziej niestosowne żarty" ${ }^{\prime 4}$.

H. Pietras uważa jednak, że uwagi poczynione przez biskupa Cezarei nie dotyczą początku kontrowersji, ale jej późniejszego przebiegu. W przekonaniu

${ }^{28}$ Por. Ayres, Nicaea and its Legacy, s. 105-130.

${ }^{29}$ Por. Epistula Constantini imperatoris ad Alexandrum Alexandrinum et Arium, w: Eusebius, Vita Constantini II 68, GCS 7, 75.

${ }^{30}$ Por. Pietras, Sobór Nicejski, s. 105.

${ }^{31}$ Por. Eusebius, Vita Constantini II 61, 2, ed. F. Winkelmann, GCS 7, 72, thum. T. Wnętrzak: Euzebiusz z Cezarei, Życie Konstantyna, ŹMT 44, Kraków 2007, 161.

${ }^{32}$ Por. tamże.

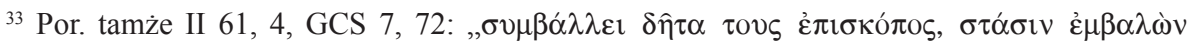

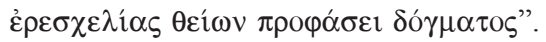

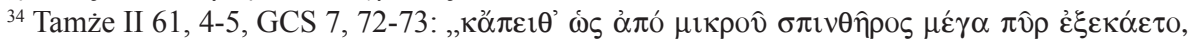

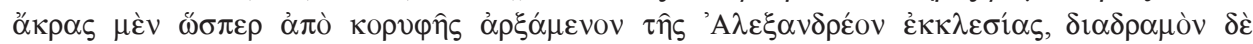

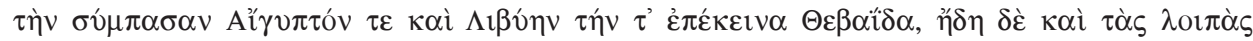

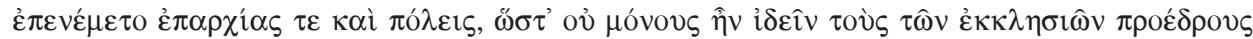

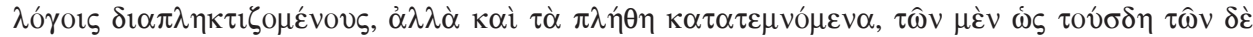

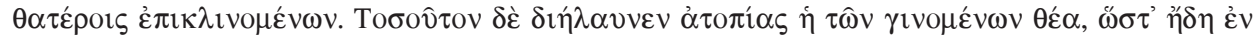

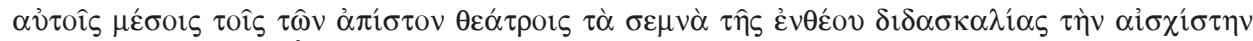

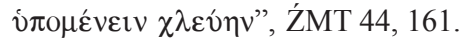


Badacza Euzebiusz zastosował tu swego rodzaju skrót myślowy ${ }^{35}$. Trzeba jednak pamiętać, że Euzebiusz z Cezarei zmarł ok. 340 roku, a spór wokół nauczania Ariusza został wyciszony przez cesarza Konstantyna zmarłego trzy lata wcześniej. Eskalacja kontrowersji ariańskiej nastapiła zaś już po śmierci obydwu $^{36}$. W kolejnym zaś rozdziale swego dzieła biskup Cezarei jeszcze raz podkreślał, że konflikt szybko zyskał wymiar powszechny:

„Uczestnicy sporu w Aleksandrii wysłali emisariuszy do biskupów innych prowincji, którzy znów rozdzielili się na różne stronnictwa w duchu podob-nej niezgody"37.

Dalsza relacja Euzebiusza bezpośrednio następująca po przytoczonych opiniach dowodzi, że opisana przez niego sytuacja w Kościele miała miejsce zanim cesarz wysłał Hozjusza z misją do Aleksandrii. Pisał bowiem biskup Cezarei: „Gdy tylko cesarz został poinformowany o tych faktach..."

$\mathrm{W}$ liście formalnie adresowanym do Aleksandra i Ariusza, w rzeczywistości jednak skierowanym do biskupów Wschodu, cesarz Konstantyn uznał panującą między nimi niezgodę za cięższą od tej, którą rozpętali donatyści ${ }^{39}$. Władca wskazywał ponadto, że prowadzony spór zaangażował „wielką część

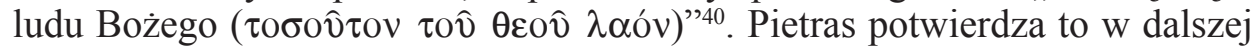
części wywodu:

„Zawoalowana treść listu nasuwa myśl - jak widzieliśmy - że był on w rzeczywistości poświęcony szerszym sprawom, i że skierowany był do Antiochii, na tamtejszy synod. Może niekoniecznie akurat do Antiochii, ale że chodzi o coś więcej niż spór dwóch duchownych z Aleksandrii, raczej rzuca się w oczy"41.

Pietras cytuje też Euzebiusza, który wskazując na niepowodzenie misji Hozjusza, konstatował:

„zajadłość walczących stron nieustannie rosła, a napór zła dosięgał już wszystkich prowincji Wschodu"42.

${ }^{35}$ Por. Pietras, Sobór Nicejski, s. 99.

${ }^{36}$ Por. Ayres, Nicaea and its Legacy, s. 105-130.

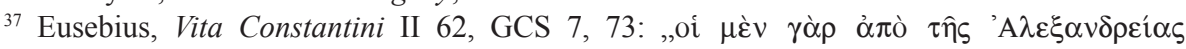

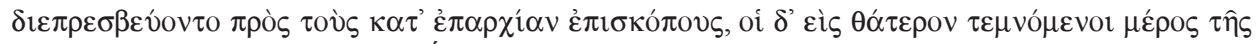

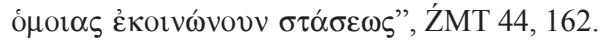

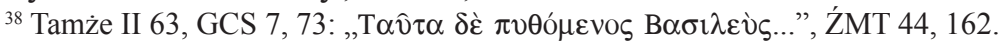

${ }^{39}$ Por. Epistula Constantini imperatoris ad Alexandrum Alexandrinum et Arium, w: Eusebius, Vita Constantini II 68, GCS 7, 75.

${ }^{40}$ Por. tamże II 71, 1, GCS 7, 76, ŹMT 44, 165.

${ }^{41}$ Pietras, Sobór Nicejski, s. 117.

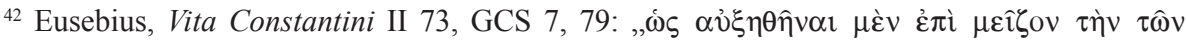

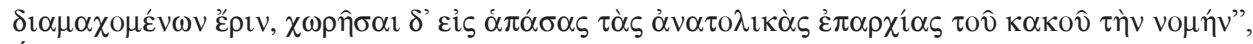
ŹMT 44, 167. 
Wyraźnie więc widać, że kontrowersja zwana ariańską przestała mieć charakter lokalny i to zanim cesarz wysłał Hozjusza z misją do Aleksandrii. Wbrew wyrażonym wcześniej opiniom Autor wspomnianej monografii wydaje się mieć tego świadomość, kiedy pisze,

,że cesarz wierzył w powodzenie misji Hozjusza, czyli w porozumienie między Aleksandrem i Ariuszem i w uspokojenie nastrojów na Wschodzie"43.

W innym zaś miejscu Pietras wyraża przekonanie, że Konstantyn był świadom, iż spór Aleksandra z Ariuszem spowodował rozdarcie w Kościele:

„i to zdaje się, że nie tylko w Kościele lokalnym w Aleksandrii, ale i na całym Wschodzie" 44 .

Mimo to jednak kilka stron dalej Badacz nadal utrzymuje, że we wrześniu lub październiku 324 r. cesarz uważał kontrowersję ariańską za spór lokalny ${ }^{45}$.

Zdaniem Autora List Konstantyna do Aleksandra i Ariusza dowodzi, że władca uważał przedmiot sporu za błahy, a sam konflikt za wewnętrzny problem Kościoła aleksandryjskiego, w którym spowodował poważny zamęt ${ }^{46}$. Konstatuje dalej:

„Pozostaje faktem, że problemem dla cesarza był gorszący spór, burzący jedność Kościoła, a nie kwestie doktrynalne" ${ }^{47}$.

I tu Autor ma niewątpliwie rację. H. Pietras, analizując fragment Listu Konstantyna do Aleksandra i Ariusza, wskazuje, że w literaturze przedmiotu nadanie tak małej rangi przedmiotowi sporu tłumaczy się powszechnie ignorancją Konstantyna na temat chrześcijaństwa. Badacz doszedł przy tym do wniosku, że władca „,rzeczywiście uważa ten spór za mało ważny”48, jednak w analizowanym tekście cesarz nazwał konflikt sporem „,o rzeczy małe i naprawdę po-

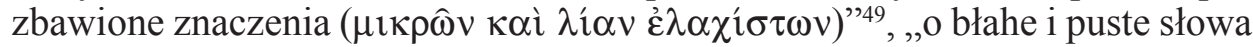

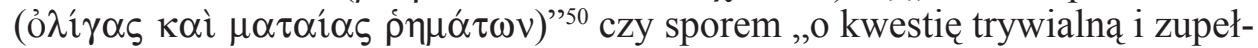

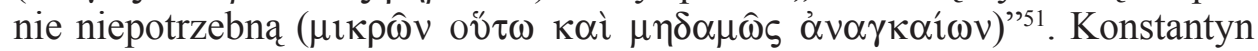
nie postrzegał zatem samego sporu za mało ważny, a jedynie tak oceniał jego materię. Spór był bowiem brzemienny w skutki - skłócił wielką część ludu Bożego, doprowadził do rozdarcia Kościoła i wzbudził wrogość jednych braci przeciw drugim. Zaniechanie kłótni przez winowajców miało przywrócić,

\footnotetext{
${ }^{43}$ Pietras, Sobór Nicejski, s. 119.

${ }^{44}$ Tamże, s. 117.

${ }^{45}$ Por. tamże, s. 126.

${ }^{46}$ Por. tamże, s. 61 i 105-106.

${ }^{47}$ Tamże, s. 117.

${ }^{48}$ Tamże, s. 110.

${ }^{49}$ Epistula Constantini imperatoris ad Alexandrum Alexandrinum et Arium, w: Eusebius, Vita Constantini II 71, 1, GCS 7, 76, ŹMT 44, 165.

${ }^{50}$ Tamże II 71, 3, GCS 7, 77, tłum. własne.

${ }^{51}$ Tamże, ŹMT 44, 166.
} 
w przekonaniu władcy, jedność całemu ludowi ${ }^{52}$. Nieco dalej wskazywał władca, że nie zazna spokoju dopóki lud Boży będzie podzielony ,,przez nie-

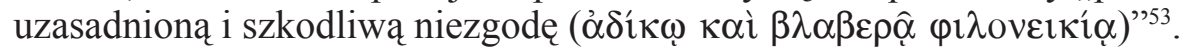

Kolejną kwestią budzącą wątpliwości jest nie tyle teza o zwołaniu soboru do Nicei z innych powodów niż kontrowersja ariańska, co przytaczane przez Autora na jej uzasadnienie argumenty. H. Pietras zwrócił uwagę, że Euzebiusz z Cezarei w Vita Constantini wskazywał na trzy sprawy, które nurtowały cesarza przed soborem w Nicei. Były wśród nich: spór Aleksandra z Ariuszem, schizma melecjańska oraz kwestia daty Wielkanocy ${ }^{54}$. Według interpretacji Badacza Euzebiusz poświęcił pierwszej z nich jedną linijkę, drugiej jedno zdanie, a ostatniej cały rozdział i na dodatek uznał brak jej uregulowania za „najcięższą chorobę" 55 .

Autor zwrócił uwagę, że w swoim liście skierowanym do Kościołów po soborze w Nicei ${ }^{56}$ cesarz Konstantyn wspomniał o dwóch kwestiach wypracowanych w czasie obrad: jedności w wierze oraz ustalaniu wspólnej dla całego Kościoła daty Paschy, podczas gdy o arianizmie i potępieniu arian nie było tam mowy ${ }^{57}$. Badacz nie bierze jednak pod uwagę, że dla wspomnianego władcy, zabiegającego o jedność Kościoła, kwestia arianizmu nigdy nie istniała, a zamieszanie wokół sporu biskupa Aleksandra z Ariuszem zostało ostatecznie wyciszone na soborze w Nicei, dzięki przyjętemu na nim credo ${ }^{58}$. W przekonaniu H. Pietrasa treść Listu władcy do Kościołów odpowiada przekazowi Euzebiusza z Cezarei, wedle którego powodem zwołania soboru była kwestia jedności wiary i ustalenie daty Wielkanocy ${ }^{59}$. Natomiast Atanazy, „tylekroć” powtarzający informację o potępieniu Ariusza w Nicei, ,nie przedstawił żadnego soborowego tekstu na poparcie swych słów" ${ }^{60}$. Biskup Aleksandrii nigdy nie zacytował Listu Konstantyna do Kościoła Aleksandrii ${ }^{61}$ czy też Listu soboru w Nicei do Egip$\operatorname{cjan}^{62}$, wspominających o potępieniu Ariusza i jego zwolenników, toteż Badacz uznał je za sfałszowane. Sądzi On bowiem, że listy owe, obydwa skierowane do Kościoła w Aleksandrii, winien był znać Atanazy, tym bardziej że był biskupem

${ }^{52}$ Por. tamże II 71, 8, GCS 7, 78.

${ }^{53}$ Tamże II 72, 1, GCS 7, 78, ŹMT 44, 167.

${ }^{54}$ Por. Pietras, Sobór Nicejski, s. 96-97.

${ }^{55}$ Por. tamże, s. 97.

${ }^{56}$ Por. Epistula Constantini imperatoris ad omnes ecclesias, ed. H.-G. Opitz, w: Athanasius, Werke, III, Leipzig - Berlin 1934, 54-57 (Urkunde 26).

${ }^{57}$ Por. Pietras, Sobór Nicejski, s. 207.

${ }^{58}$ Por. S. Bralewski, Cesarz Konstantyn I Wielki wobec kontrowersji ariańskiej, Labarum VIII, Poznań 2009, passim.

${ }^{59}$ Por. Pietras, Sobór Nicejski, s. 207-208.

${ }^{60}$ Tamże, s. 208.

${ }^{61}$ Por. Epistula Constantini imperatoris ad ecclesiam Alexandrinam, ed. H.-G. Opitz, w: Athanasius, Werke, III, s. 52-54 (Urkunde 25).

${ }^{62}$ Por. Epistula concilii Nicaeni ad ecclesiam Alexandrinam et episcopos Aegypti, Libyae et Pentapolis, ed. H.-G. Opitz, w: Athanasius, Werke, III, s. 47-51 (Urkunde 23). 
tegoż miasta. Uważa, że gdyby były autentyczne, bardzo przydałyby się mu $\mathrm{w}$ walce $\mathrm{z}$ arianami i melecjanami. Ponieważ nigdy $\mathrm{z}$ nich nie skorzystał ani nawet o nich nie wspomniał, to znaczy, że nie był świadom ich istnienia. Tak więc Autor przypuszcza, że obydwa powstały już po śmierci Atanazego najprawdopodobniej po roku 373, ale przed dekretem Teodozjusza o wierze nicejskiej wydanym 10 stycznia 381 roku $^{63}$. Zdaniem $\mathrm{H}$. Pietrasa jednak nie ma powodu wątpić, że w Nicei dyskutowano także sprawę Ariusza ${ }^{64}$.

W obydwu listach znajduja się ostre frazy skierowane przeciwko Ariuszowi i jego nauce, co może zaskakiwać, zważywszy na neutralność cesarza, manifestowaną już w Liście do Aleksandra i Ariusza, oraz na zróżnicowanie duchownych zgromadzonych w Nicei, jeśli chodzi o ich poglądy teologiczne. Trzeba jednak pamiętać, że Ariusz nie zaakceptował kompromisowego credo z trudem wypracowanego pod patronatem władcy w Nicei i wtedy stał się dla Konstantyna błędnowierca, tym, który „uległ mocy szatańskiej”65. Podobnie na temat Ariusza wypowiadał się cesarz w datowanym na rok $333^{66}$ Liście do biskupów $i$ ludu, w którym ogłaszał bardzo surowe prawo skierowane przeciwko Ariuszowi i jego zwolennikom, zapowiadając karę śmierci dla ukrywających przed spaleniem dzieła napisane przez Ariusza ${ }^{67}$. Ostatni z wymienionych listów zamieścił Atanazy w swoim dziele O dekretach Soboru Nicejskie$g o^{68}$ i dokument ten choćby z tego względu trzeba uważać za wiarygodny. Jeśli osiem lat po soborze, na mniej więcej dwa lata przed oficjalną rehabilitacją Ariusza na synodzie w Jerozolimie (335), cesarz zajmował tak radykalne stanowisko, potępiając Ariusza, to musiał mieć ku temu solidną podstawę w decyzji zgromadzonych w Nicei. Gdyby sobór nie potępił Ariusza, podtrzymując wcześniejszą anatemę rzuconą nań przez Aleksandra, biskupa Aleksandrii, cesarz nie miałby powodu, aby wydawać przeciwko niemu tak surowe prawo. Samo potępienie Ariusza w Aleksandrii przed soborem w Nicei nie byłoby do tego wystarczającym powodem, jak sugeruje to H. Pietras w odpowiedzi na recenzję Wojciecha Stawiszyńskiego ${ }^{69}$. Znamienne, że sam Atanazy, choć nie cytował dwóch pierwszych z wymienionych listów, to w Apologii przeciw

${ }^{63}$ Por. Codex Theodosianus XVI 5, 6, ŹMT 71 [tekst łacińsko-polski, oprac. M. Ożóg M. Wójcik, wstęp M. Stachura, tłum. A. Caba], Kraków 2014 = SCL 7, 43-44. Zob. też Pietras, Sobór Nicejski, s. 209.

${ }^{64}$ Por. Pietras, Sobór Nicejski, s. 120 i 208.

${ }^{65}$ Epistula Constantini imperatoris ad ecclesiam Alexandrinam, ed. Opitz, III, s. 53, thum. S.J. Kazikowski: List cesarza, w: Sokrates Scholastyk, Historia Kościoła, Warszawa 1986, 90.

${ }^{66}$ Por. H.-G. Opitz, Komentarz, w: Athanasius, Werke, III, s. 38.

${ }^{67}$ Por. Lex lata Constantini Augusti de Arii damnatione, ed. H.-G. Opitz, w: Athanasius, Werke, III, s. 37-38.

${ }^{68}$ Por. Athanasius, De decretis Nicaenae synodi, ed. H.-G. Opitz, w: Athanasius, Werke, III, s. 37-38.

${ }^{69}$ Por. W. Stawiszyński (recenzja książki): H. Pietras, Sobór Nicejski (325). Kontekst religijny i polityczny, dokumenty, komentarze, Kraków 2013, VoxP 34 (2014) t. 61, 570-571; H. Pietras, Odpowiedź na recenzję W. Stawiszyńskiego, VoxP 35 (2015) t. 63, 564. 
arianom pisał o potępieniu przez Sobór Nicejski herezji oraz arian i przyjęciu do jedności kościelnej melecjan, co wyraźnie współgrało z ich treścią ${ }^{70}$.

Patrolog zwraca też uwagę, że podobnie jak w przypadku potępienia Ariusza i jego zwolenników Atanazy nie przytacza też żadnego soborowego tekstu dotyczącego przyjęcia melecjan do wspólnoty Kościoła. Nie twierdzi jednak na tej podstawie, że kwestia ta nie została przez sobór rozstrzygnięta ${ }^{71}$. Odwrotnie też, mimo że Badacz dostrzegł podobieństwo rozwiązań proponowanych wobec melecjan w Liście Soboru Nicejskiego do Egipcjan z rozporządzeniami zamieszczonymi w ósmym kanonie tegoż soboru, dotyczącymi tych, „którzy zwą się czystymi”, utożsamianymi przez Patrologa zarówno z montanistami, donatystami, nowacjanami, jak i melecjanami ${ }^{72}$, a Atanazy nie powoływał się również na treść owego kanonu w walce z tymi ostatnimi, nie stało się to dla H. Pietrasa powodem do twierdzenia, że kanon ów został sfałszowany. Skoro tę normę prawną można wiązać z melecjanami, Atanazy, jak się wydaje, równie dobrze mógłby powoływać się na List Soboru do Egipcjan, jak i właśnie na nią. Jeśli tego nie robił, to prawdopodobnie dlatego, że nie podobała mu się decyzja dotycząca przyjęcia melecjan do wspólnoty Kościoła, podjęta przez zgromadzonych w Nicei. W przekonaniu samego Badacza Atanazy zadowolony z niej nie by ${ }^{73}$. Toteż z jednej strony przynamniej niektórym $\mathrm{z}$ nich blokował dostęp do kościołów, jak wskazywal Hermiasz Sozomen ${ }^{74}$, a z drugiej z innymi postępował wedle wytycznych zawartych we wspomnianym liście ${ }^{75}$. H. Pietras sądzi jednak, że to nie Atanazy realizował wytyczne listu w relacjach z melecjanami, ale wypracowana przez niego praktyka postępowania z nimi znalazła odzwierciedlenie $\mathrm{w}$ tymż $\mathrm{e}^{76}$. Teza ta wydaje się jednak nie mieć należytego uzasadnienia, tak jak i ta dotycząca sfałszowania wspomnianych listów.

Zasadniczym argumentem, jakim Badacz szermuje na poparcie lansowanego przez siebie twierdzenia o zwołaniu soboru do Nicei z innych powodów niż kontrowersja ariańska, jest, jego zdaniem, zaniechanie zimą w czasach Imperium Romanum żeglugi na Morzu Śródziemnym. Dowodzi to, wedle Badacza, niemożliwości zwołania soboru po zakończeniu misji Hozjusza, który mógł z niej wrócić dopiero późną wiosną 325 r., a wtedy nie było już możliwości zebrania biskupów z całego cesarstwa w czerwcu. Problem w tym,

${ }^{70}$ Por. Athanasius, Apologia contra arianos 59, 3, ed. H.-G. Opitz, w: Athanasius, Werke, III, s. 139.

${ }^{71}$ Por. Pietras, Sobór Nicejski, s. 208.

${ }^{72}$ Por. tamże, s. 201. Także w moim przekonaniu ósmy kanon z Nicei dotyczył wszystkich rygorystów określających się mianem czystych. Zob. S. Bralewski, Did the bishops ordered by Emperor Constantine the Great to gather at Nicea discuss the Donatist schism?, w: Saint Emperor Constantine and Christianity, ed. D. Bojović, vol. 1, Niš 2013, 209-211.

${ }^{73}$ Por. Pietras, Sobór Nicejski, s. 201-202.

${ }^{74}$ Por. Sozomenus, HE II 22, 1, ed. J. Bidez - G.C. Hansen, GCS NF 4, Berlin 1995, 78.

${ }^{75}$ Por. A. Martin, Les conditions de la readmission du clergé mélitien par le concile de Nicée, „Ancient Society" 20 (1989) 281-290.

${ }^{76}$ Por. Pietras, Sobór Nicejski, s. 202. 
że zdania na temat zamknięcia żeglugi zimą są podzielone ${ }^{77}$. Można bowiem wskazać na liczne przypadki żeglowania o tej porze roku i to nawet całymi flotami. Trzeba było wszak zaopatrywać wielkie miasta w zboże przez cały rok, nawet zimą. Konieczność podjęcia podróży sprawiała, że zimowa pora roku nie powstrzymywała przed żeglugą duchownych, czego dowodzą przykłady Grzegorza z Nazjanzu czy Synezjusza. Trafnie rzecz ujął Stanisław Ducin:

„Wydaje się, że to nie pora roku, lecz aktualny stan pogodowy wyznaczał czas żeglugi zarówno Rzymianom, jak i dużo lepiej rozwiniętej nawigacji greckiej. [...] W starożytności podobnie, jak w epokach późniejszych, zawsze musiało nastapić skonfrontowanie dwóch podstawowych czynników: celu żeglugi i ewentualnych zysków oraz związanego z nimi ryzyka"78.

Tak więc nie można wykluczyć, że przy dobrej pogodzie Hozjusz takie ryzyko mógł podjaćc $c^{79}$.

Pamiętać jednak trzeba po pierwsze, że sama misja Hozjusza trwała dłuższy czas, skoro uczestniczył on w Aleksandrii w obradach synodu; a po drugie, że Hozjusz, stając po stronie Aleksandra a przeciw Ariuszowi, sprzeniewierzył się cesarzowi, który oczekiwał od niego pojednania zwaśnionych. Nie miał więc powodu, żeby nadmiernie spieszyć się z powrotem na dwór cesarski. Gdyby jednak założyć, że powrócił tam jeszcze przed synodem w Antiochii, któremu najprawdopodobniej przewodniczy ${ }^{80}$, co mógłby uczynić tylko jako legat cesarski, to czy władca, znając jego poglądy, kolejny raz powierzyłby mu misję pojednania zwaśnionych? Wydaje się, że nie. Tak więc prawdopodobnie Hozjusz przybył do Antiochii bezpośrednio z Aleksandrii. Na synodzie antiocheńskim nie tylko uchwalono antyariańskie credo, ale też poinformowano o wielkim zgromadzeniu, jakie miało odbyć się w Ancyrze. Trudno przypuszczać, aby Hozjusz miał w tej sprawie samowolnie podjąć decyzję. Musiała być ona wcześniej uzgodniona $\mathrm{z}$ władcą, a zatem bardzo realne jest, że sobór został zwołany zanim biskup Kordoby wyruszył do Egiptu.

Jeśli zatem prawdopodobne jest, że to nie kwestia ariańska zadecydowała o konwokacji soboru, z jakich powodów mógł zostać zwołany? Przyczyny podane przez Autora trzeba brać również pod uwagę, ale w moim przekonaniu zasadniczym motywem, którym mógł kierować się władca, był zamiar położenia kresu schizmie donacjańskiej. W tej to sprawie bez powodzenia organizował już synody, najpierw rzymski (313), a potem generalny dla zachodniej części Imperium w Arles (314). Z Listu do Aleksandra i Ariusza wyraźnie wynika,

${ }^{77}$ Por. J. Rougé, La navigation hivernale sous l'Empire romain, REA 54 (1952) 316-325.

${ }^{78}$ S. Ducin, Sztuka nawigacji w starożytnej Grecji i Rzymie, Lublin 1997, 66.

${ }^{79}$ Zwracał na to uwagę W. Stawiszyński w recenzji omawianej książki H. Pietrasa (VoxP 34:2014, t. 61, 567-569), jednak jej Autor pozostał przy swoim zdaniu. Por. H. Pietras, Odpowiedź na recenzję W. Stawiszyńskiego, s. 563-564.

${ }^{80}$ Por. H. Chadwick, Ossius of Cordova and the Presidency of the Council of Antioch, 325, JTS 9 (1958) 292-304. 
że cesarz zamierzał przy pomocy biskupów Wschodu „dostarczyć lekarstwo na błędy" donatystów ${ }^{81}$, a można przypuszczać, że uświadomiono mu, iż obok nich jedność Kościoła rozbijali także inni rygoryści, jak melecjanie czy nowacjanie. Do podobnych wniosków doszedł H. Pietras, wskazując, że cesarza niepokoiła zarówno schizma donacjańska, jak i melecjańska ${ }^{82}$. W każdym razie Konstantyn uznał donatystów za winnych schizmy w Kościele kartagińskim. Odwoływał się do coraz to nowych autorytetów wskazywanych przez donatystów z nadzieją, że w końcu zaakceptują wydany w ich sprawie wyrok. Oczekiwał tego zarówno po niewielkim liczebnie synodzie w Rzymie (313), jak i po znacznie większym synodzie w Arles (314). Następnie spodziewał się, bo takie nadzieje dawali mu donatyści, że uznają oni w swojej sprawie autorytet monarszy. Dlatego sam rozsądził toczony przez nich spór w Mediolanie (316), jednak i tym razem nie udało się zakończyć schizmy. W końcu wobec oporu pars Donati Konstantyn zarządził represje skierowane przeciwko jej zwolennikom (317), aby po kilku latach z nich zrezygnować, uznając ich nieskuteczność (321). Czy po wojnie z Licyniuszem, kiedy zjednoczył cesarstwo pod swoją władzą, Konstantyn mógł zrezygnować z dalszych wysiłków zakończenia schizmy w Afryce, skoro tak bardzo mu na tym wcześniej zależało? Jak się wydaje, do przywrócenia pokoju wśród tamtejszych chrześcijan cesarz zamierzał wykorzystać tym razem autorytet zgromadzenia biskupów całego Kościoła, co odpowiadało pewnej logice dotychczasowego postępowania wobec donatystów - odwoływania się w ich sprawie do kolejnych autorytetów ${ }^{83}$. Sam Autor zresztą doszedł do wniosku, że dla Konstantyna przyczyna schizmy donacjańskiej była poważniejsza od przyczyny kontrowersji ariańskiej, gdyż pierwsza dotyczyła praktyki dyscyplinarnej Kościoła, bezpośrednio związanej z kultem, druga natomiast nie dotyczyła kwestii praktycznych, a jedynie doktrynalnych, czego władca nie potrafił zrozumieć ${ }^{84}$. Niewątpliwie inną ważną dla cesarza sprawą, której bez wspólnej decyzji wschodnich i zachodnich biskupów ustalić się nie dało, była data obchodzenia Wielkanocy, o czym przekonał się władca (na co zwrócił uwagę H. Pietras), prawdopodobnie próbując nakłonić zebranych przez siebie biskupów do jej ujednolicenia na synodzie w Arles w 314 roku. Ci jednak nic konkretnego w tej materii nie postanowili, a jedynie wyrazili wolę, by wszystkie Kościoły obchodziły Wielkanoc w tym samym dniu ${ }^{85}$. Bez wschodnich biskupów tak ważnej sprawy nie dało się skutecznie rozwiązać.

Jeśli chodzi o datę rozpoczęcia soboru, Autor opowiada się za 19 czerwca, gdyż za takim datowaniem z jednej strony przemawia cesarski list, informujący

${ }^{81}$ Por. Epistula Constantini imperatoris ad Alexandrum Alexandrinum et Arium, w: Eusebius, Vita Constantini II 66-68, 1-2, GCS 7, 74-75, ŹMT 44, 163-164.

${ }^{82}$ Por. Pietras, Sobór Nicejski, s. 118.

${ }^{83}$ Por. Bralewski, Czy cesarz Konstantyn Wielki, s. 427-448; tenże, Did the bishops, s. 203-211.

${ }^{84}$ Por. Pietras, Sobór Nicejski, s. 106.

${ }^{85}$ Por. tamże, s. 124. 
biskupów o przeniesieniu obrad z Ancyry do Nicei, który zachował się w wersji syryjskiej ${ }^{86}, \mathrm{z}$ drugiej natomiast świadectwo soboru w Chalcedonie ${ }^{87}$. Data wskazana przez Sokratesa z Konstantynopola - 20 maja $^{88}$, wydaje się Pietrasowi nazbyt wczesna, by mogli zdążyć na nią biskupi z całego cesarstwa, wyruszający po Wielkanocy, tym bardziej że tę w roku 325 obchodzono 18 kwietnia. Badacz dowodzi, że decyzja o zwołaniu soboru musiała zapaść przed misją Hozjusza z Kordoby, gdyż po jej zakończeniu nie było wystarczającego czasu, aby zgromadzić biskupów już w czerwcu na obradach, tym bardziej, że zimą nie żeglowano, a Hozjusz wyruszył w drogę do Aleksandrii późną jesienią. Ponieważ Konstantyn oczekiwał, że biskup Kordoby pojedna zwaśnionych, nie mógł więc w tej sprawie zwoływać biskupów z całego cesarstwa. Skoro zatem do konwokacji soboru nie doszło z powodu arianizmu, to i uchwały wspomnianego zgromadzenia nie mogły mieć charakteru antyariańskiego. W przekonaniu Badacza taki fałszywy obraz soboru narzucili historycy kościelni piszący ponad sto lat po jego obradach: Sokrates z Konstantynopola, Hermiasz Sozomen i Teodoret z Cyru, którzy kierowali się relacją Atanazego z Aleksandrii, skrajnie antyariańską ${ }^{89}$.

Autor przyjmuje całkowicie za wiarygodną relację Euzebiusza z Cezarei na temat soboru, dowodząc, że po pierwsze był on współczesny wydarzeniom, a poza tym jego relacja nie została oprotestowana przez innych uczestników owego zgromadzenia, a przede wszystkim niechętnego mu Atanazego z Aleksandrii. Dlatego uważa on relację Euzebiusza za bardziej wiarygodną od relacji wspomnianych historyków ${ }^{90}$. Euzebiusz natomiast w liście skierowanym do wiernych swego Kościoła bezpośrednio po zakończeniu soboru, choć nadmienia o dyskusjach doktrynalnych prowadzonych na soborze na temat wyznania wiary, „ani jednym słowem nie wspomina o potępieniu Ariusza" ${ }^{1}$. List ten dołączył do swego dzieła Atanazy ${ }^{92}$ nie podważając jego wiarygodności. Dlaczego jednak Euzebiusz w liście poświęconym przyjętej na soborze formule wiary miałby wspominać o potępieniu przez zgromadzonych Ariusza? Tym bardziej że cesarz, organizator obrad biskupów, dążył do pojednania zwaśnionych w oparciu o wypracowany w sprawach wiary kompromis i nie zamierzał nikogo odrzucać. Ariusz zaś owego kompromisu nie zaakceptował, przeto pozostał poza wspólnotą Kościoła, z której został już wcześniej wyłączony przez swojego biskupa Aleksandra.

${ }^{86}$ Por. Epistula Constantini imperatoris ad episcopos (syriace), ed. H.-G. Opitz, w: Athanasius, Werke, III, s. 41 (Urkunde 20).

${ }^{87}$ Por. Acta Conciliorum Oecumenicorum II: Concilium Universale Chalcedonense 3, 2, ed.

E. Schwartz, Berolini - Lipsiae 1936, 264.

${ }^{88}$ Por. Socrates, HE I 13, 13, ed. G.C. Hansen, GCS NF 1, Berlin 1995, 51.

${ }^{89}$ Por. Pietras, Sobór Nicejski, s. 137-138.

${ }^{90}$ Por. tamże, s. 138.

91 Tamże, s. 191.

${ }^{92}$ Por. Athanasius, De decretis Nicaenae synodi 3, 5, ed. Opitz, III, s. 3. 
H. Pietras nie ma wątpliwości, że wyrażenie ó borze cesarz, co zresztą sugerował Euzebiusz z Cezarei ${ }^{93}$, gdyż żeby wpaść na ten pomysł, trzeba było, zdaniem Badacza, nie znać się na teologii, który to warunek cesarz spełniał w całej rozciąłłości. W przekonaniu Autora nie można bowiem wskazać nikogo, kto byłby orędownikiem tego terminu ${ }^{94}$. Co prawda z relacji Sozomena wynika, że zaakceptował owo wyrażenie Aleksander z Aleksandrii, ale uczynił to nie bez wahania ${ }^{95}$. Pietras widzi w tym jednak posunięcie taktyczne, gdyż Aleksander nie używał go w swych pisemnych wypowiedziach $^{96}$. Badacz podkreśla, że jedynie Euzebiusz pozytywnie wypowiedział się o tym wyrażeniu w liście do wiernych swego Kościoła po soborze w Nicei, podczas gdy Atanazy z Aleksandrii, sztandarowa postać związana z soborem w Nicei, miał zacząć posługiwać się tym terminem dopiero 25 lat po soborze. Co prawda Euzebiusz wspomniał, że terminem ó sługiwali się w dawnych czasach niektórzy uczeni, wybitni biskupi i pisarze, kiedy wykładali naukę o Ojcu i Synu - Słowie Bożym, ale nie są oni dzisiaj znani $^{97}$. Nawet na synodzie w Sardyce nie wspomniano nicejskiego wyznania wiary, a kluczowe pojęcie nicejskiego credo ov̉oí $\alpha$ określono jako heretyc$\mathrm{kie}^{98}$. Autor zauważył także, że w prowadzonej dyskusji teologicznej obawiano się konotacji materialnych wyrażenia ó $\mu$ oov́oı $\varsigma^{99}$.

W końcu H. Pietras widzi legendę w informacji o ułożeniu na soborze konstantynopolitańskim credo i opowiada się za hipotezą celowego fałszerstwa, służącego wymuszeniu na Rzymie uznania dla Konstantynopola w Kościele. W instytucji tej liczyła się bowiem nie tylko sukcesja apostolska, ale także miejsce w tradycji soborowej. Dlatego, Jego zdaniem, starano się wzmocnić rangę miasta jakimś argumentem kościelnym, a tym miało być credo nicejskie uzupełnione o konieczny dopisek o Duchu Świętym przeciwko macedonianom, przez co wprowadzano Konstantynopol do ekskluzywnego klubu najważniejszych miast chrześcijaństwa, już nie tylko ze względu na stołeczność, ale i soborowośćc ${ }^{100}$.

H. Pietras wydaje się być niekonsekwentny, jeśli chodzi o czas, w którym Atanazy, biskup Aleksandrii, sformułował swoją opinię o antyariańskim charakterze soboru w Nicei i potępieniu na nim arian. Jak podkreśla Patrolog, skromne wiadomości na temat soboru Atanazy zawarł we wspomnianym już dziele $O$ dekretach Soboru Nicejskiego (350) ${ }^{101}$, a znana powszechnie relacja

\footnotetext{
${ }^{93}$ Por. Epistula Eusebii Caesariensis ad Caesarienses, ed. G.C. Hansen, w: Socrates, HE I 8 , 35-54, GCS NF 1, 23-27.

${ }^{94}$ Por. Pietras, Sobór Nicejski, s. 170.

${ }^{95}$ Por. Sozomenus, HE I 15, 5-6, GCS NF 4, 33.

${ }^{96}$ Por. Pietras, Sobór Nicejski, s. 171.

${ }^{97}$ Por. tamże, s. 175.

${ }^{98}$ Por. tamże, s. 185.

${ }^{99}$ Por. tamże, s. 32.

${ }^{100}$ Por. tamże, s. 186-188.

${ }^{101}$ Por. Athanasius, De decretis Nicaenae synodi, ed. Opitz, III, s. 1-45.
} 
Atanazego z obrad soboru w Nicei pochodzi dopiero z roku $370^{102}$. Wedle Badacza list synodu aleksandryjskiego z roku 338/339103,

„który odbywał się pod przewodnictwem Atanazego, mówi tylko, że Atanazy na Soborze Nicejskim wypowiadał się przeciwko Ariuszowi. [...] Nie uznano za stosowne nadmienić, że w Nicei z poparciem cesarza miano by potępić Ariusza" 104 .

Wedle H. Pietrasa wskazywał na to dopiero dwa lata późniejszy list synodu rzymskiego ${ }^{105}$, który jednak, w przekonaniu Badacza, odzwierciedlał ,aktualne zdanie Atanazego"106. Czyli biskup Aleksandrii już w roku 340 dowodził potępienia arian przez sobór w Nicei, a więc 15 lat po nicejskich obradach. W innym miejscu swej monografii ${ }^{107}$ Patrolog cytuje Apologię przeciw arianom, w której Atanazy mówi wprost o potępieniu arian na Soborze Nicejskim

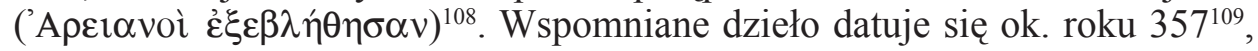
a więc i to świadectwo znacznie poprzedza rok 370.

Generalnie jednak trudno zgodzić się z tezą stawianą przez H. Pietrasa, zaprzeczająca potępieniu Ariusza na soborze w Nicei. Przy czym Autor stawia znak równości między potępieniem Ariusza a antyariańskim charakterem soboru. Niewątpliwie Badacz ma rację, dowodząc, że sobór antyariański nie był, w pierwszym przypadku jednak się myli, gdyż źródła dowodzą rzeczy przeciwnej. Zgadzam się z Autorem co do tego, że credo nicejskie było kompromisem, którego oczekiwał cesarz od biskupów ${ }^{110}$. Myślę, iż mimo dopre-

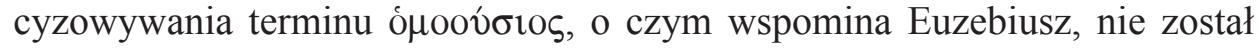
on ściśle zdefiniowany, bo przecież władca, sugerując, że kwestia okryta jest tajemnica przez samego Boga, przerwał dyskusję ${ }^{111}$. Uczestnicy soboru musieli zatem różnorako rozumieć owo wyrażenie. Rozbieżne opinie nie dawały nadziei na uzgodnienie stanowisk. Dalsze prowadzenie dysputy groziło zaś poważnym rozłamem. Z punktu widzenia władcy jedynie pozostawienie zgromadzonym możliwości w miarę swobodnej jego interpretacji mogło zapewnić pokój. Dzięki temu prawie wszyscy byli skłonni, acz z oporami, podpisać się pod credo. $Z$ kompromisami jednak tak bywa, że nie zadowalają żadnej ze stron. Trudno się zatem dziwić, że przez wiele lat podchodzono z dystansem

${ }^{102}$ Por. Pietras, Sobór Nicejski, s. 191-192.

${ }^{103}$ Por. Epistula synodi Alexandriae, ŹMT 37 [tekst grecko-polski, układ i oprac. A. Baron H. Pietras, tłum. J. Ożóg], Kraków 2006 = SCL 1, 93-109.

${ }^{104}$ Pietras, Sobór Nicejski, s. 192.

${ }^{105}$ Por. Epistula Iulii papae, SCL 1 [tekst grecko-polski, tłum. J. Ożóg], 110-123.

${ }^{106}$ Pietras, Sobór Nicejski, s. 192.

${ }^{107}$ Por. tamże, s. 201.

${ }^{108}$ Athanasius, Apologia contra arianos 59, 3, ed. Opitz, III, s. 139.

${ }^{109}$ Por. Opitz, Komentarz, w: Athanasius, Werke, III, s. 87; SWP 57.

${ }^{110}$ Por. Bralewski, Polityka Konstantyna Wielkiego wobec Arian, s. 335-355.

${ }^{111}$ Por. Epistula Eusebii Caesariensis ad Caesarienses, w: Socrates, HE I 8, 42-43, GCS NF 1, 25. 
do nicejskiego wyznania, aż do czasu, kiedy jedna ze stron narzuciła swoją

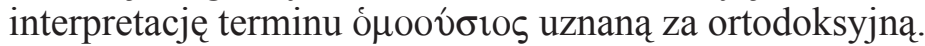

Ponieważ w Nicei zawarto kompromis, żadna grupa biorąca udział w jego wypracowaniu nie została potępiona, także ci klasyfikowani przez swoich przeciwników jako arianie. Sobór więc nie miał charakteru antyariańskiego, jak sugerował potem obóz Atanazego. Jak zostali jednak potraktowani ci, którzy kompromis odrzucili? Ariusz był jedynie prezbiterem, to prawda, ale przecież do niego, obok biskupa Aleksandra, zwracał się cesarz z prośbą o zaniechanie kłótni, uznając tym samym obydwu za sprawców zamieszania i to jest fakt. Czy możliwe więc byłoby, żeby na soborze, który antyariański nie był, dano tylko biskupowi możliwość zaakceptowania kompromisu, a prezbitera takiej szansy pozbawiono? Skoro władca nie lekceważył go wcześniej, dlaczego miałby to robić nieco później? Wydaje się to bardzo mało prawdopodobne. Przy czym oczywiście nie chodzi o jego pełnoprawny udział w obradach, do czego jako prezbiter nie miał prawa. Wiemy, że Ariusz przyjął uchwały nicejskie dopiero w jakiś czas po soborze, ostatecznie przed synodem w Jerozolimie w roku 335, co jest kolejnym niepodważalnym faktem. Dowodzi to, że przez jakiś okres nie chciał ich zaakceptować, a więc je odrzucał. Czy sobór, a przede wszystkim sam władca, mogli taką postawę tolerować? Wydaje się to nieprawdopodobne. Dla Konstantyna jeden ze sprawców sporu, Aleksander, okazał się człowiekiem otwartym na kompromis, co musiało się spotkać z uznaniem władcy, który takiej postawy oczekiwał od zgromadzonych duchownych. Drugi sprawca natomiast, Ariusz, odrzucając ugodę, okazał się prawdziwym wichrzycielem. Już na tej tylko podstawie można śmiało założyć potępienie Ariusza w Nicei zaraz po tym, jak odmówił podpisania credo.

Nie tylko kwestionowane przez H. Pietrasa listy zawierają informację o potępieniu Ariusza i jego zwolenników. Wbrew sugestiom Badacza w liście synodu aleksandryjskiego z roku $338 / 339^{112}$ również jest mowa o potępieniu arian przez sobór. Biskupi nadmieniają, że Teognist z Nicei i Euzebiusz z Nikomedii zostali złożeni z urzędów za to, że podtrzymywali łączność $\mathrm{z}$ arianami, potępionymi przez sobór. W moim przekonaniu potwierdza to list przypisywany przez Sokratesa ${ }^{113}$ czy Sozomena ${ }^{114}$ Euzebiuszowi z Nikomedii i Teognisowi z Nicei. Ich autorstwo wykluczyła Annik Martin ${ }^{115}$, przypisując ów list zesłanym na wygnanie w tym samym czasie co Ariusz dwóm biskupom libijskim, Sekundusowi z Ptolemaidy i Teonasowi z Marmaryki, i datując go na rok 335, a więc po synodzie w Jerozolimie. Za jej koncepcją opowiada się Pierre Maraval ${ }^{116}$. To prawda, że w liście tym nie pada imię Ariusza, ani

${ }^{112}$ Por. Epistula synodi Alexandriae 8, 2, SCL 1, 99.

${ }^{113}$ Por. Epistula Eusebii Nicomediensis et Theognii Nicaeensis ad episcopos, ed. G.C. Hansen, w: Socrates, HE I 14, 2-6, GCS NF 1, 52-53.

${ }^{114}$ Por. Sozomenus, HE II 16, 3-7, GCS NF 4, 71.

115 Por. A. Martin, Le Fil d'Arius: 325-335, RHE 84 (1989) 297-333.

116 Por. P. Maraval, w: SCh 477, Paris 2004, 166, nota. 2. 
nawet sama nazwa Nicei. Mowa jest jednak o tym, że adresaci zgodzili się na tezy wiary świętej po sumiennym zbadaniu pojęcia ó $\mu$ oov́oıs. Sprzeciwili się jednak podpisaniu pod ekskomuniką. Nie wskazali czyją. Autorzy listu tłumaczyli, że zrobili tak nie dlatego, aby występować przeciwko wierze, ale z powodu wątpliwości co do winy skazanego. Wyraźnie w dalszej części listu składają na niego całą odpowiedzialność za konflikt, widząc w nim głównego winowajcę. Jeśli ten, winny całego zamieszania, ma być odwołany z wygnania, to dlaczego oni, którzy znaleźli się tam z jego powodu, mają tkwić nadal na wygnaniu. O kogo może zatem chodzić autorom listu, jeśli nie o Ariusza i jego ekskomunikę na soborze w Nicei. Okoliczność niewymienienia Ariusza z imienia może dowodzić, że jego potępienie przez sobór było faktem powszechnie znanym. Wszyscy adresaci doskonale wiedzieli o kogo chodzi. Jako winowajcę musiał też postrzegać Ariusza sam władca po jego odmowie zaakceptowania credo.

Cytowany za Atanazym przez H. Pietrasa ${ }^{117}$ fragment listu synodu w Jerozolimie z roku 335 mówi o przyjęciu z powrotem do Kościoła zwolenników Ariusza, co znaczy, że zostali z niego wcześniej wykluczeni. Na wyłączenie ze wspólnoty Kościoła wprost wskazuje list Ariusza i Euzojusza skierowany do cesarza Konstantyna, a cytowany przez Sokratesa ${ }^{118}$, w którym obydwaj wyznają swoją wiarę i zapewniają, że podzielają wiarę i nauczanie Kościoła Powszechnego, a także, że porzucili dociekliwość i nadmierne dysputy, a ich pragnieniem jest pokój. Przedstawione fakty dowodzą zatem niezbicie ekskomuniki Ariusza. Nawet jeśli nie wszystkie z tych świadectw bezpośrednio wskazują na sobór w Nicei jako sprawcę potępienia Ariusza, to wykazują niewątpliwie, że w czasie obrad tego zgromadzenia ani bezpośrednio po nim prezbiter ów nie zaakceptował ułożonego przez nie credo. Zrobił to $\mathrm{w}$ bliżej nieokreślonym czasie przed synodem w Jerozolimie. Jeśli tak, to należał do wąskiego grona, które sprzeciwiło się uchwałom soboru. Jego potępienie przez sobór wydaje się więc oczywiste. Sformułowanie użyte przez uczestników synodu w Jerozolimie o tym, że zwolennicy Ariusza ,przez pewien czas wskutek niegodziwej zawiści byli poza Kościołem" ${ }^{119}$, może odnosić się do czasu bezpośrednio poprzedzającego ów synod i zabiegów Ariusza o powrót na łono Kościoła, torpedowanych przez Atanazego.

Sam H. Pietras zwrócił uwagę ${ }^{120}$, że synod rzymski z roku 340 wraz z papieżem Juliuszem, stając w obronie Atanazego, wspomniał w liście posynodalnym o potępieniu arian przez wszystkich uczestników wielkiego soboru w Nicei ${ }^{121}$. Dla Badacza list ten jednak ma niewielką wartość, z tej racji, że

${ }^{117}$ Por. Pietras, Sobór Nicejski, s. 192.

${ }^{118}$ Por. Epistula Arii et Euzoii ad Constantinum imperatorem, ed. G.C. Hansen, w: Socrates, HE I 26, GCS NF 1, 74-75.

${ }^{119}$ Epistula synodi Hierosolymitani, SCL 1 [tekst grecko-polski, tłum. J. Ożóg - A. Caba], 92.

${ }^{120}$ Por. Pietras, Sobór Nicejski, s. 192.

${ }^{121}$ Por. Epistula Iulii papae, SCL 1, 112. 
napisano go 15 lat po soborze, a jego autorzy nie podali szczegółów dotyczących wspomnianego przez nich potępienia. W dodatku H. Pietras jest przekonany, że informację na ten temat spreparował sam Atanazy. Wydaje się jednak, że Autor popełnia błąd, skoro w dalszej części wspomnianego listu ${ }^{122}$ jest jeszcze mowa o zdemaskowaniu wobec uczestników synodu Pistusa z Aleksandrii, którego prezbiterzy Atanazego określili jako arianina i wskazali, że został on wyrzucony przez biskupa Aleksandra i sobór w Nicei, podobnie jak jego konsekrator Sekundus, którego sobór także wyłączył ze wspólnoty jako arianina. Prezbiter Makary i diakoni Martyriusz i Hezychiusz, wysłannicy wschodnich biskupów, ,nie przeczyli temu”, jak wynika z treści listu ${ }^{123}$. Nie protestowali przeciwko temu także biskupi zebrani w Antiochii na kolejnym synodzie w roku 341. Skupili się na czymś zupełnie innym. Wykazywali - „nie idziemy za Ariuszem - jakżeż, będąc biskupami, mielibyśmy iść za prezbiterem?"124. Nie dowodzili zatem, iż nieprawdą jest potępienie Ariusza w Nicei, że jest to wymysł Atanazego i jego prezbiterów. Uznali za nadużycie przyklejanie zrehabilitowanym przez nich duchownym, a pośrednio im samym, etykiety arian i przeciwko temu oponowali.

Trzeba jeszcze raz zaznaczyć, że Ariusz został w Nicei potępiony dlatego, że nie zaakceptował kompromisu z trudem wypracowanego na soborze. Jak dowodzi list cesarza Konstantyna skierowany do Aleksandra i Ariusza, władca nie zamierzał nikogo potępiać. Jego celem było przywrócenie jedności Kościoła w oparciu o kompromis i tak, jak się wydaje, trzeba postrzegać

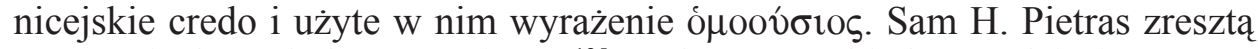
nazywa je formułą kompromisową ${ }^{125}$. Dobrym przykładem podejścia cesarza do ówczesnego konfliktu w Kościele jest los Euzebiusza z Cezarei. Potępiony na synodzie w Antiochii zgodnie z kościelnymi zwyczajami nie powinien być pełnoprawnym członkiem soboru, dopóki nie została zdjęta z niego ekskomunika. Fakt, że stało się inaczej, możemy tylko tłumaczyć wolą cesarza. Euzebiusz nie tylko kompromis zaakceptował, ale aktywnie uczestniczył w jego wypracowaniu, za co zyskał uznanie władcy. Gdyby Ariusz poszedł od razu w jego ślady, cesarz nie dopuściłby do jego potępienia. Kwestią jednak zasadniczą jest fakt, że dopóki żył Konstantyn, credo nicejskie było oficjalną formułą wiary Kościoła, gdyż taka była jego wola, co nie znaczy, że było powszechnie przyjęte. Tutaj Autor ma całkowicie rację. Natomiast wyznanie wiary „tych ludzi” (zwolenników Ariusza), o którym wspomina list synodu jerozolimskiego ${ }^{126}$, nie miało charakteru oficjalnego, ale wyraźnie sam władca uczynił wyłom, dopuszczając inną formułę wiary jako ortodoksyjną, co potwierdził synod.

\footnotetext{
${ }^{122}$ Por. tamże, SCL 1, 113.

${ }^{123}$ Por. tamże, SCL 1, 110.

${ }^{124}$ Synodus in encaeniis - Prima formula fidei, SCL 1 [tekst grecko-polski, thum. A. Baron], 129.

${ }^{125}$ Por. Pietras, Sobór Nicejski, s. 214.

${ }^{126}$ Por. Epistula synodi Hierosolymitani, SCL 1, 92.
} 
Generalnie jednak z nowymi formułami wiary zgromadzenia biskupów zaczęły występować dopiero po śmierci Konstantyna, co trzeba bardzo mocno podkreślić. Cesarz Konstantyn zachował w trakcie kontrowersji ariańskiej neutralność. Nie opowiedział się przeciw arianom podczas soboru w Nicei, tak jak i po stronie arian po zamknięciu obrad. Postawił na kompromis i do końca swego życia uważał go za jeden z fundamentów jedności Kościoła. W głębokim przekonaniu władcy po zakończeniu soboru kwestia kontrowersji ariańskiej przestała istnieć ${ }^{127}$. Tak więc sobór w Nicei nie miał charakteru antyariańskiego, mimo że Ariusz został na nim potępiony.

Badacz podkreśla, że cesarz ,jako pontifex maximus odpowiedzialny za wszystkie religie świata, interesował się żywo problemami Kościoła" ${ }^{28}$. Wychodząc z założenia, że jednym z najważniejszych obowiązków najwyższego kapłana było przechowywanie świętych formuł wszystkich religii i czuwanie, by wierni do nich się stosowali, doszedł do wniosku, że władca nie dysponował żadnym tekstem chrześcijańskim, co uniemożliwiało mu czuwanie nad prawidłowością chrześcijańskiego kultu. Biskupi brali pod uwagę credo własnego Kościoła, a cesarz potrzebował dokumentu ogólniejszej natury i w tym celu prawdopodobnie zwołał sobór do Nicei. Wcześniejsze zgromadzenia biskupów nie układały swoich formuł wiary. Jako pierwszy uczynił to dopiero synod w Antiochii, któremu prawdopodobnie przewodniczył Hozjusz. Pietras nie wyklucza więc, że to cesarz powierzył biskupowi Kordoby w ramach misji wschodniej sformułowanie credo, które jednak na tyle nie zadowoliło władcy, że nie wspomniano nawet o nim na soborze, na którym powstało nowe wyznanie wiary ${ }^{129}$.

Koncepcja H. Pietrasa ma jednak słabe strony. Po pierwsze, dlaczego cesarz wychowany w religii pogańskiej, dla której kwestie doktrynalne były obce, miałby domagać się ułożenia credo, a więc sporządzenia dokumentu ze swej natury mającego charakter doktrynalny? Tym bardziej że jednocześnie sam w Liście do Aleksandra i Ariusza wyrażał kompletny brak zrozumienia dla prowadzonego przez nich sporu i namawiał, aby każdy z nich zaniechał eksponowania swoich poglądów. Po drugie, czy władca mógł powierzyć Hozjuszowi zadanie ułożenia kompromisowego symbolu wiary, a jednocześnie nie oczekiwać wypracowania przez głównych adwersarzy wspólnego stanowiska w dzielących ich kwestiach teologicznych? Po trzecie, dlaczego wcześniej cesarz nie domagał się od synodu w Arles, zwołanego w roku 314, będącego synodem generalnym dla zachodniej części Imperium Romanum, ułożenia formuły wiary, skoro już wówczas nosił tytuł pontifex maximus?

H. Pietras, zwracając uwagę na mowę wygłoszoną przez cesarza Konstantyna na soborze w Nicei, uznał za znaczące nazwanie w niej biskupów

${ }^{127}$ Por. Bralewski, Cesarz Konstantyn I Wielki wobec kontrowersji ariańskiej, passim, gdzie szerzej wyłożyłem swoje poglądy na ten temat.

${ }^{128}$ Por. Pietras, Sobór Nicejski, s. 95.

${ }^{129}$ Por. tamże, s. 128-129. 
„kapłanami Chrystusa” oraz to, iż mowę tę cesarz wygłosił po łacinie ${ }^{130}$. Badacz widzi w niej przemówienie najwyższego pontyfika do kolegium kapłańskiego:

„Konstantyn przemówił zatem jako pontifex maximus, językiem oficjalnym tego urzędu i chcąc ogłosić datę Wielkanocy, proklamował również zgromadzenie biskupów jako kolegium kapłańskie chrześcijaństwa"131.

Badacz podkreśla w swojej książce, że cesarz ,jako pontifex maximus odpowiedzialny za wszystkie religie świata, interesował się żywo problemami Kościoła"132. Wydaje się jednak, że zainteresowanie cesarza chrześcijaństwem wynikało nie tyle z jego kompetencji najwyższego kapłana, ile przede wszystkim z racji błogosławieństwa, jakiego, w swoim najgłębszym przekonaniu, doznał od Chrystusa, odnosząc szereg zwycięstw militarnych ${ }^{133}$. Niewątpliwie cesarz czuł się zobowiązany wobec Boga do nadzorowania spraw Kościoła, co zgadzało się z rzymską tradycją, wedle której władcy, sprawując funkcję najwyższego kapłana (pontifex maximus), nadzorowali kulty religijne. Co do mowy wygłoszonej przez cesarza Konstantyna na soborze w Nicei i określenia w niej biskupów „kapłanami Chrystusa”"134, to trzeba zauważyć, że w jej wersji zacytowanej przez Euzebiusza z Cezarei nie pojawia się określenie „kapłani Chrystusa", na którym H. Pietras buduje swoją tezę o proklamowaniu soboru kolegium kapłańskim chrześcijaństwa. Występuje ono w tekście Sozomena ${ }^{135}$ piszącego sto lat później. Zacytowana przez niego mowa nie jest tą samą, którą zamieścił Euzebiusz ${ }^{136}$, choć jej treść jest podobna. Wydaje się, jakby Sozomen dokonał jej skrótu, sparafrazował ja, ale uczynił to jednak ponad sto lat po soborze w Nicei.

Niezwykle ciekawa monografia autorstwa H. Pietrasa poświęcona soborowi w Nicei jest też niewątpliwie poważnym osiągnięciem naukowym, jakkolwiek wiele spośród opinii tak wyraziście sformułowanych przez Autora budzi kontrowersje, co pozwoliłem sobie przedstawić w formie polemiki. Omawiana książka zmusza czytelnika do gruntownych przemyśleń na temat faktów, które zostały już powszechnie zinterpretowane i sklasyfikowane. Jej szczególną

\footnotetext{
${ }^{130}$ Por. tamże, s. 140.

${ }^{131}$ Tamże, s. 140-141.

132 Tamże, s. 95.
}

${ }^{133}$ Por. S. Bralewski, Constantinian Shift - The Truth or a Myth?, VoxP 34 (2014) t. 61, 3953; tenże, Przełom konstantyński a religijność Rzymian w wiekach IV $i$ V-wybrane zagadnienia, w: Bitwa przy Moście Mulwijskim. Konsekwencje, red. Z. Kalinowski - D. Próchniak, Poznań

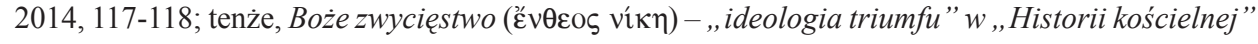
Euzebiusza z Cezarei, VoxP 35 (2015) t. 63, 331-351.

${ }^{134}$ Por. Pietras, Sobór Nicejski, s. 140.

${ }^{135}$ Por. Sozomenus, HE I 19, 3, GCS NF 4, 40.

${ }^{136}$ Por. Eusebius, Vita Constantini III 12, GCS 7, 82-83. 
wartością jest dokonywana przez Autora z dużą erudycją analiza źródeł, która zmusza czytelnika do przeprowadzenia własnego dochodzenia. Reasumując zaś najistotniejsze kwestie, przyznać trzeba Badaczowi rację, kiedy dowodzi, że sobór zwołany najpierw do Ancyry, a potem przeniesiony do Nicei, nie został zorganizowany z powodu kontrowersji ariańskiej. Wydaje się jednak, że jego właściwą przyczyną była przede wszystkim schizma donacjańska, której Patrolog nie docenił, a obok niej kwestia ujednolicenia terminu świętowania Paschy ${ }^{137}$. Z całą pewnością też sobór nie miał charakteru antyariańskiego, jednak Ariusz został na nim potępiony jako ten, który odrzucił wypracowany $\mathrm{z}$ trudem w Nicei kompromis w postaci credo i wyrażenia ó

\section{ON THE COUNCIL OF NICEA (325) \\ IN THE LIGHT OF THE MONOGRAPH BY HENRYK PIETRAS SJ}

\section{(Summary)}

The Council convened by emperor Constantine the Great to Nicea in the year 325 still arouses keen interest of researchers around the world. Against the background of international scholarship, the achievements of Polish academics look quite modest. That is why one should especially appreciate the publication of a book (written in Polish) on the subject by Henryk Pietras, an acclaimed Polish patrologist. The monograph is noteworthy for a number of reasons and compels the reader to a thorough reflection on a cornucopia of facts that have been already discussed by numerous academics and subject to manifold interpretations. Its special merit lies first and foremost in an erudite analysis of sources conducted by the Author, which is competent enough to exhort all the interested to (at least) re-think their views. It is necessary to admit that the Academic is right, when he argues that the Council (firstly convened to Ancyra, and subsequently to Nicea) was not organized for the reason of discussing the Arian controversy. In reality, it seems that the primary reason for the meeting was the Donatist schism, which the Patrologist underestimated, and additionally the problem of reaching an agreement on a date of the Passover celebration. Certainly, the Council was not of an anti-Arian nature, but Arius was condemned by the ecclesiastic meeting as the one who rejected a laboriously reached compromise as for the form of the credo and renounced the term homoousios.

Key words: Council of Nicaea, emperor Constantine, Arius, Arianism, symbol of faith, Donatism.

Słowa kluczowe: Sobór Nicejski, cesarz Konstantyn, Ariusz, arianizm, symbol wiary, donatyzm.

${ }^{137} \mathrm{Na}$ brak podstaw źródłowych do twierdzeń o zwołaniu soboru z racji 20. rocznicy panowania Konstantyna zwracał już uwagę W. Stawiszyński w swojej recenzji książki H. Pietrasa (VoxP $34: 2014$, t. 61, 569). 


\section{BIBLIOGRAFIA}

Źródła

Acta Conciliorum Oecumenicorum II, ed. E. Schwartz, Berolini - Lipsiae 1936.

Athanasius, Apologia contra arianos, ed. H.-G. Opitz, w: Athanasius, Werke, III, Leipzig - Berlin 1934, 85-168.

Athanasius, De decretis Nicaenae synodi, ed. H.-G. Opitz, w: Athanasius, Werke, III, Leipzig - Berlin 1934, 1-45.

Codex Theodosianus XVI, tekst łacińsko-polski, oprac. M. Ożóg - M. Wójcik, wstęp M. Stachura, tłum. A. Caba, ŹMT 71 = SCL 7, Kraków 2014.

Epiphanius, Panarion 65-80, De fide, ed. K. Hall - J. Dummer, GCS 37, Berlin - New York 2009.

Epistula Alexandri Alexandrini ad Alexandrum Constantinopolitanum, ed. L. Parmentier

- G.C. Hansen, w: Theodoretus Cyrensis, Historia ecclesiastica I 4, 1-61, GCS NF 5 , Berlin - New York 2009, 8-25.

Epistula Arii et Euzoii ad Constantinum imperatorem, ed. G.C. Hansen, w: Socrates, Historia ecclesiastica I 26, GCS NF 1, Berlin 1995, 74-75.

Epistula Arii presbiteri ad Eusebium Nicomediensis, ed. L. Parmentier - G.C. Hansen, w: Theodoretus Cyrensis, Historia ecclesiastica I 5, 1-4, GCS NF 5, Berlin - New York 2009, 26-27.

Epistula concilii Nicaeni ad ecclesiam Alexandrinam et episcopos Aegypti, Libyae et Pentapolis, ed. H.-G. Opitz, w: Athanasius, Werke, III, Leipzig - Berlin 1934, 47-51 (Urkunde 23).

Epistula Constantini imperatoris ad Alexandrum Alexandrinum et Arium, ed. F. Winkelmann, w: Eusebius, Vita Constantini II 64-72, GCS 7, Berlin - New York 2008, 74-79.

Epistula Constantini imperatoris ad ecclesiam Alexandrinam, ed. H.-G. Opitz, w: Athanasius, Werke, III, Leipzig - Berlin 1934, $52-54$ (Urkunde 25), tłum. S.J. Kazikowski: List cesarza, w: Sokrates Scholastyk, Historia Kościoła, Warszawa 1986, 89-91.

Epistula Constantini imperatoris ad episcopos (syriace), ed. H.-G. Opitz, w: Athanasius, Werke, III, Leipzig - Berlin 1934, 41-42 (Urkunde 20).

Epistula Constantini imperatoris ad omnes ecclesias, ed. H.-G. Opitz, w: Athanasius, Werke, III, Leipzig - Berlin 1934, 54-57 (Urkunde 26).

Epistula Eusebii Caesariensis ad Caesarienses, ed. G.C. Hansen, w: Socrates, Historia ecclesiastica I 8, 35-54, GCS NF 1, Berlin 1995, 23-27.

Epistula Eusebii Nicomediensis ad Paulinum Tyronensis, ed. L. Parmentier - G.C. Hansen, w: Theodoretus Cyrensis, Historia ecclesiastica I 6, 1-8, GCS NF 5, Berlin New York 2009, 27-29.

Epistula Eusebii Nicomediensis et Theognii Nicaeensis ad episcopos, ed. G.C. Hansen, w: Socrates, Historia ecclesiastica I 14, 2-6, GCS NF 1, Berlin 1995, 52-53.

Epistula Iulii papae, tekst grecko-polski, układ i oprac. A. Baron - H. Pietras, tłum. J. Ożóg, ŹMT 37 = SCL 1, Kraków 2006, 110-123.

Epistula synodi Alexandriae, tekst grecko-polski, układ i oprac. A. Baron - H. Pietras, tłum. J. Ożóg, ŹMT 37 = SCL 1, Kraków 2006, 93-109.

Epistula synodi Hierosolymitani, tekst grecko-polski, układ i oprac. A. Baron - H. Pietras, tłum. J. Ożóg - A. Caba, ŹMT 37 = SCL 1, Kraków 2006, 92-93. 
Eusebius, Vita Constantini, ed. F. Winkelmann, GCS 7, Berlin - New York 2008, thum.

T. Wnętrzak: Euzebiusz z Cezarei, Życie Konstantyna, ŹMT 44, Kraków 2007.

Lex lata Constantini Augusti de Arii damnatione, ed. H.-G. Opitz, w: Athanasius, Werke, III, Leipzig - Berlin 1934, 37-38.

Philostorgius, Historia Ecclesiastica, ed. J. Bidez-F. Winkelmann, GCS 21, Berlin 1981. Socrates, Historia Ecclesiastica, ed. G.C. Hansen, GCS NF 1, Berlin 1995; ed. P. Maraval, SCh 477, Paris 2004.

Sozomenus, Historia Ecclesiastica, ed. J. Bidez - G.C. Hansen, GCS NF 4, Berlin 1995, thum. S. Kazikowski: Hermiasz Sozomen, Historia Kościoła, Warszawa 1989.

Synodus in encaeniis - Prima formula fidei, tekst grecko-polski, układ i oprac. A. Baron H. Pietras, tłum. A. Baron, ŹMT 37 = SCL 1, Kraków 2006, 129.

\section{Opracowania}

AlÈs A. d', Le dogme de Nicée, Paris 1926.

Anatolios K., Retrieving Nicaea. The Development and Meaning of Trinitarian Doctrine, Michigan 2011.

Ayres L., Nicaea and its Legacy. An Approach to Fourth-Century Trinitarian Theology, Oxford 2004.

Barnes T.D., Constantine and Eusebius, London 1981.

Behr J., The Nicene Faith, Crestwood - New York 2004.

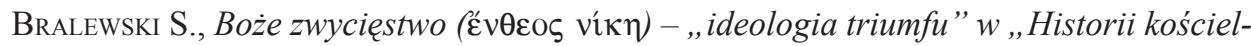
nej” Euzebiusza z Cezarei, VoxP 35 (2015) t. 63, 331-351.

Bralewski S., Cesarz Konstantyn I Wielki wobec kontrowersji ariańskiej, Labarum VIII, Poznań 2009.

Bralewski S., Constantinian Shift - The Truth or a Myth?, VoxP 34 (2014) t. 61, 39-53.

Bralewski S., Czy cesarz Konstantyn Wielki zabiegat o kompromis z donatystami?, VoxP 20 (2000) t. 38-39, 427-448.

Bralewski S., Did the bishops ordered by Emperor Constantine the Great to gather at Nicea discuss the Donatist schism?, w: Saint Emperor Constantine and Christianity, vol. 1, ed. D. Bojović, Niš 2013, 203-215.

Bralewski S., Polityka Konstantyna Wielkiego wobec Arian po soborze w Nicei: nagty zwrot czy kontynuacja? VoxP 18 (1998) t. 34-35, 335-355.

Bralewski S., Przełom konstantyński a religijność Rzymian w wiekach IV i V-wybrane zagadnienia, w: Bitwa przy Moście Mulwijskim. Konsekwencje, red. Z. KalinowskiD. Próchniak, Poznań 2014, 115-149.

CHadwick H., Ossius of Cordova and the presidency of the Council of Antioch, 325, JTS 9 (1958) 292-304.

Duncin S., Sztuka nawigacji w starożytnej Grecji i Rzymie, Lublin 1997.

Ferguson T.C., The Past is Prologue. The Revolution of Nicene Historiography, Leiden - Boston 2005.

GLIŚCIŃSKi J., Wspótistotny Ojcu, Łódź 1992.

Grzywaczewski J., Okoliczności zwołania Soboru Nicejskiego, VoxP 34 (2014) t. 62, 139-168.

Hanson R.P.C., The Search for the Christian Doctrine of God. The Arian Controversy 318-381, Edinburgh 1988. 
Hefele C.J., Histoire des conciles d'après les documents originaux, trad. H. Leclerq, t. 1, Paris 1907.

Longosz S., Liczba uczestników I Soboru Nicejskiego (325) w relacji Ojców Kościoła IV w., w: Ku prawdzie w miłości. Księga Pamiatkowa ks. bpa J. Śrutwy, red. S. Koczwara, Lublin 2002, 71-86.

LuiBHÉid C., The Council of Nicea, Galway 1982.

Martin A., Le Fil d'Arius: 325-335, RHE 84 (1989) 297-333.

Martin A., Les conditions de la readmission du clergé mélitien par le concile de Nicée, „Ancient Society” 20 (1989) 281-290.

Ortiz de Urbina I., Nicée et Constantinople, Paris 1963.

Pietras H., Le ragioni della convocazione del Concilio Niceo da parte di Constantino il Grande. Un’investigazione storico-teologica, „Gregorianum” 82/1 (2001) 5-35.

Pietras H., List Konstantyna do Aleksandra i Ariusza a zwołanie soboru Nicejskiego, VoxP 26 (2006) t. 64, 531-547.

Pietras H., List Konstantyna do Kościoła Aleksandrii oraz list soborowy do Egipcjan (325) - falsyfikaty nieznane Atanazemu?, VoxP 28 (2008) t. 52/2, 855-869.

Pietras H., Odpowiedź na recenzję W. Stawiszyńskiego, VoxP 35 (2015) t. 63, 563-565.

Pietras H., Poczqtek „,kontrowersji ariańskiej”, Zeszyty Naukowe UJ, Studia Religiologica 39, Kraków 2006, 57-79.

Pietras H., Sobór Nicejski (325). Kontekst religijny i polityczny, dokumenty, komentarze, Kraków 2013.

Rouge J., La navigation hivernale sous l'Empire romain, REA 54 (1952) 316-325.

Simoneti M., La crisi ariana nel IV secolo, Roma 1975.

SŁomka J., Symbol Nicejski, w: Wolność w prawdzie. Księga Jubileuszowa Instytutu Teologicznego w Łodzi, red. S. Skobel, Łódź 1997, 125-140.

SŁomKa J., Z historii interpretacji nicejskiego wyznania wiary, „Łódzkie Studia Teologiczne" 3 (1994) 323-338.

SpychaŁa D., Cesarze rzymscy a arianizm od Konstantyna Wielkiego do Teodozjusza Wielkiego (312-395), Poznań 2007.

Starowieyski M., Sobory Kościoła niepodzielonego, Tarnów 1994, 17-33.

Stawiszyński W., [rec.] H. Pietras, Sobór Nicejski (325). Kontekst religijny i polityczny, dokumenty, komentarze, Kraków 2013, VoxP 34 (2014) t. 61, 567-572.

Stead G.C., Divine Substance, Oxford 1977.

Williams R., Arius: Heresy and Tradition, London 1987.

WoliŃSKi J., Sobór Nicejski zwrotnym punktem w nauczaniu patrystyki, VoxP 9 (1989) t. $16,191-211$. 